\title{
Origin and nature of cold seep in northeastern Dongsha area, South China Sea: Evidence from chimney-like seep carbonates
}

\author{
HAN XiQiu ${ }^{1,2^{*}}$, YANG KeHong ${ }^{1,2}$ \& HUANG Yong Yang ${ }^{3}$ \\ ${ }^{1}$ Key Laboratory of Submarine Geosciences, State Oceanic Administration, Hangzhou 310012, China; \\ ${ }^{2}$ Second Institute of Oceanography, State Oceanic Administration, Hangzhou 310012, China; \\ ${ }^{3}$ Guangzhou Marine Geological Survey, Guangzhou 510075, China
}

Received September 20, 2012; accepted February 2, 2013; published online May 9, 2013

\begin{abstract}
The occurrence of seep carbonates is one of the characteristic features for cold seep sites at continental margins. The carbonates documented the venting history of methane-rich fluid. Compared to the chemoherm carbonates and carbonate pavements which formed on the sediment-water interface, chimney-like seep carbonates precipitated around fluid conduits below the sediment-water interface therefore better recording information of the past fluid flow and composition. Here the chimney-like seep carbonate samples from the northeastern Dongsha area of the South China Sea were studied to understand the origin and nature of the venting fluids and their potential relationship with gas hydrate deposits underneath the seafloor. Based on the occurrence, morphology, petrology, mineralogy and C- and O- isotope compositions, combined with present and past bottom water temperatures and the timing of methane release events, the oxygen isotopic fractionation between calcite and water were used to estimate the equilibrium $\delta^{18} \mathrm{O}$ values of the precipitating fluids. The $\delta^{13} \mathrm{C}$ values ranging from $-56.33 \%$ to $-42.70 \%$ V-PDB and thus clearly show that the studied chimneys were mainly derived from biogenic methane oxidation. The calculated equilibrium $\delta^{18} \mathrm{O}$ values of the precipitating fluids ranged from $1.9 \% \circ \pm 0.3 \%$ to $0.6 \% \circ \pm 0.3 \%$ V-SMOW, with an average of $1.4 \% \circ \pm 0.3 \%$ o $\mathrm{V}-\mathrm{SMOW}$ which is heavier than those of seawater even at the last glacial maximum. It is considered that the formation of chimney-like carbonates was closely related to methane hydrate dissociation in the area. The methane hydrates contributed as much as $45.7 \%$ of water to the venting fluids. It is suggested that the climate and environmental changes (e.g. sea-level lowering, down-cutting canyons and mass wasting) are the major mechanisms maybe responsible for the destabilization of methane hydrates in the study area. The extensive occurrence of seep carbonates indicates that a large amount of the methane released from methane hydrate dissociation has been effectively captured and sequestered by microbial anaerobic oxidation of methane (AOM) before it escapes into the water column.
\end{abstract}

South China Sea, seep carbonate chimneys, carbon and oxygen isotopes, gas hydrate deposits, methane-rich fluids

Citation: Han X Q, Yang K H, Huang Y Y. Origin and nature of cold seep in northeastern Dongsha area, South China Sea: Evidence from chimney-like seep carbonates. Chin Sci Bull, 2013, 58: 3689-3697, doi: 10.1007/s11434-013-5819-x

Seep carbonate fields have been discovered worldwide on active and passive continental margins [1,2]. The formation of seep carbonates is associated with the seepage of methane-rich fluids. The process of anaerobic oxidation of methane (AOM) coupled with sulfate reduction by consortia of archaea and bacteria at sulfate-methane transition zone (SMTZ) increases the alkalinity of the environment and causes the formation of seep carbonates [1,3]. The seep

*Corresponding author (email: xqhan@ sio.org.cn) carbonates have $\delta^{13} \mathrm{C}$ values usually in the range of $-20 \%$ o to $-60 \%$ V-PDB [1] and could be as low as $-75 \%$ V-PDB [2]. They are different from normal marine carbonates in carbon source and formation mechanism. According to their environment of formation, seep carbonates can be classified into two types [4-7]. One type forms at the sediment-seawater interface in contacts with bottom seawater such as chemoherm carbonates and carbonate pavements. They are usually dominated by aragonite. The other type forms within the sediments, for example as carbonate 
chimneys and nodules. They are not in contact with bottom seawater and their carbonate mineral phases are usually dominated by $\mathrm{Mg}$-calcite or dolomite [4-7]. The presence of seep carbonates indicates that the site was actively venting methane-rich fluids [1].

Seep carbonates provide an archive of fluid venting history and its potential relationship with gas hydrate deposits beneath the seafloor. Bohrmann et al. [8] measured the oxygen isotopic composition of seep carbonates from Cascadia subduction zone and showed that $\mathrm{Mg}$-calcite precipitated from ${ }^{18} \mathrm{O}$-enriched pore water. The authors suggested that the $\mathrm{Mg}$-calcites with heavy $\delta^{18} \mathrm{O}$ are likely formed from gas hydrate dissociation water. Han et al. [4] studied the seep carbonates from the Costa Rica margin, and found that the $\delta^{18} \mathrm{O}$ of the precipitating fluid was as high as $4.7 \%$ V-SMOW suggesting that it has a component of clay dehydration water associated with mud volcanoes and mud diapirs.

In 2004 three seep carbonate fields were first discovered in the northeastern slope of the South China Sea during the Sino-German SONNE 177 joint cruise $[9,10]$. They are located on two adjacent ridges separated by a submarine canyon about $8 \mathrm{~km}$ wide. Site $1\left(22^{\circ} 09^{\prime} \mathrm{N}, 118^{\circ} 52^{\prime} \mathrm{E}\right.$, water depth: 473-498 m) is located at the eastern ridge, Site 2 $\left(22^{\circ} 08^{\prime} \mathrm{N}, 118^{\circ} 43^{\prime} \mathrm{E}\right.$, water depth: $\left.533-555 \mathrm{~m}\right)$ at the northern segment of the western ridge, and Site $3\left(22^{\circ} 02^{\prime} \mathrm{N}\right.$, $118^{\circ} 46^{\prime} \mathrm{E}$, water depth: $768-771 \mathrm{~m}$ ) at the southern segment of the western ridge (Figure 1). An Ocean Floor Observation System was used to video-survey the seafloor and observe the occurrence of seep carbonates. A TV-guided grab sampler was used to collect seep carbonates $[9,10]$. Previous studies have addressed many aspects of the seep carbonate samples, including their characteristic morphology, petrology, mineralogy, C- and O-isotope compositions, rare Earth element geochemistry, preserved microbial structures, biomarkers, ages as well as model of chimney-like carbonate formations [5,9-19]. However, the origin and nature of the fluid flow and its relationship with gas hydrate deposits have not been studied thoroughly. Lu et al. [12] attempted to calculate the $\delta^{18} \mathrm{O}$ of the precipitating fluid based on the

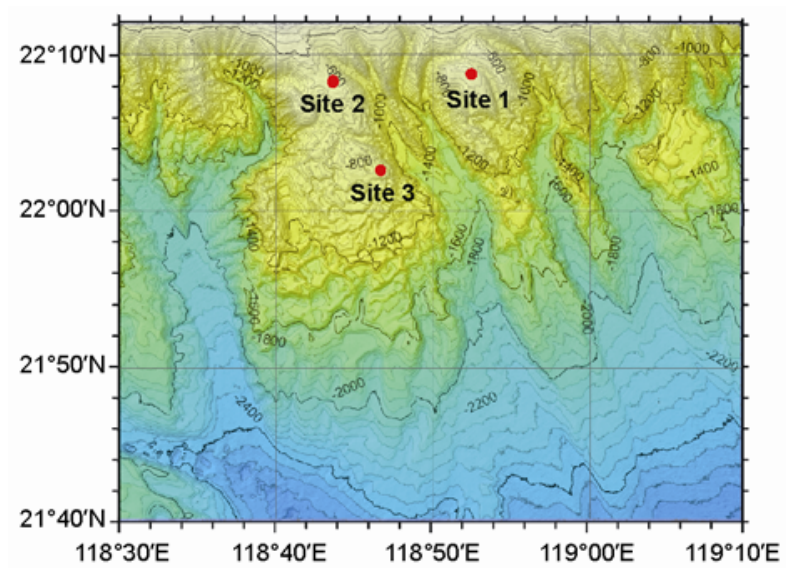

Figure 1 Map of the study area showing the location of sampling sites. $\delta^{18} \mathrm{O}$ of aragonite. The authors showed that the $\delta^{18} \mathrm{O}$ of the fluid ranged from $0.59 \%$ to $0.74 \%$ V-SMOW and suggested that the carbonates precipitated from ${ }^{18} \mathrm{O}$-enriched gas hydrate water. Since the past seawater during the low sea level stands was also ${ }^{18} \mathrm{O}$-enriched, for instance, during the last glacial maximum (LGM), the $\delta^{18} \mathrm{O}$ value of seawater was $1.05 \%$ $\pm 0.2 \%$ V-SMOW [20]. It remains uncertain whether they recorded the signal of water released from gas hydrate dissociation or isotopically heavy glacial ocean water. Since aragonite tends to form near the sedimentseawater interface [6-8,21], hence when fluids emitted from the seafloor, they are strongly diluted and therefore the signal of venting fluid recorded in aragonite would be much weaker compared to the chimney-like carbonates that precipitated around the fluid conduits below the sedimentseawater interface. In this paper, we focus on the chimneylike carbonates based on these previous studies. We aim to: (1) characterize the nature and origin of the past precipitating fluids and the possible relationship with subsurface gas hydrate deposits through reconstructing the $\delta^{18} \mathrm{O}$ values of the precipitating fluids; (2) quantify the contribution of water released from gas hydrate destabilization in the venting fluids; and (3) discuss the potential mechanisms responsible for the gas hydrate destabilization in the study area.

\section{Materials and methods}

The studied samples were collected in Sites 1, 2 and 3 during SO177 cruise (Figure 1). In total, 175 pieces of the chimney-like carbonate samples were described and measured. Representative samples were selected and examined in thin sections for petrographic characteristics. Sub-samples were analyzed for mineralogy and stable isotope compositions. X-ray diffraction (XRD) analysis for the bulk mineralogy was determined by a Philips PW 1820 X diffractometer with $\mathrm{Cu} \mathrm{K}$-alpha radiation. The mol-percentage of $\mathrm{Mg}$ in calcite was calculated from the $d$ [104] lattice-shift [22]. Carbon- and O-isotope ratios were measured on a Finnigan MAT 252 mass spectrometer. $\mathrm{CO}_{2}$ extraction for $\delta^{13} \mathrm{C}$ and $\delta^{18} \mathrm{O}$ measurements was carried out with pure $\mathrm{H}_{3} \mathrm{PO}_{4}$ at $75^{\circ} \mathrm{C}$. All data are reported in permil (\%o) relative to the Pee Dee Belemnite (V-PDB) standard. Replicate analyses of a laboratory standard show a standard deviation $<0.03 \%$ for $\delta^{13} \mathrm{C}$ and $<0.05 \%$ o for $\delta^{18} \mathrm{O}$.

\section{Results}

\subsection{Occurrence and morphology of the chimney-like seep carbonates}

Based on the ocean floor observation, the chimney-like seep carbonates occur in patches on the seafloor. Some protrude from the sediments vertically (Figure 2a), some have been exhumed and toppled over on the seafloor by current, similar 

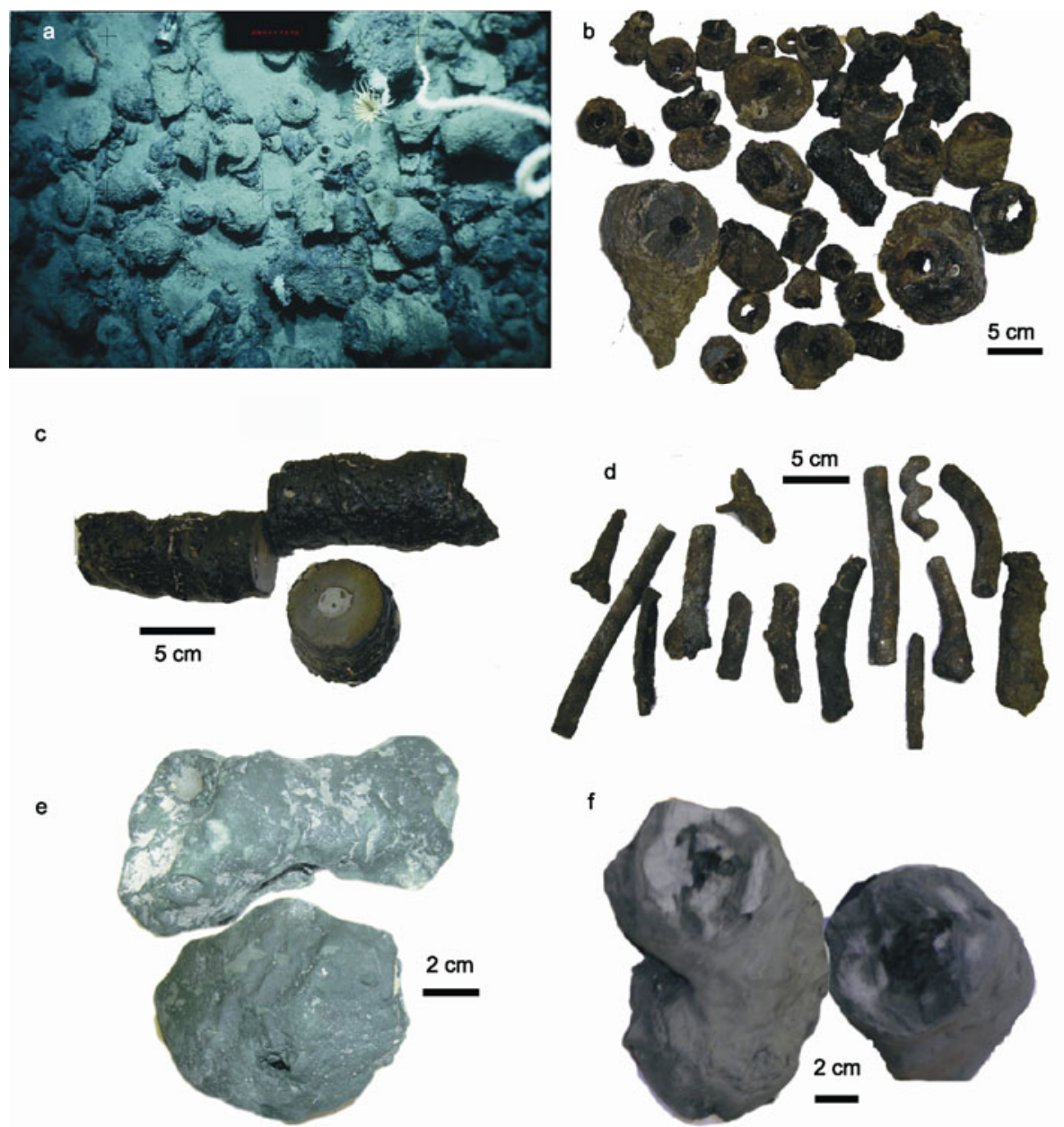

Figure 2 Types of the chimney-like carbonates from the northeastern Dongsha, South China Sea. a, Seafloor image showing the occurrence of chimney-like carbonates; b, Doughnut-shaped chimneys, Site 2; c, tubular chimney, the fluid conduit has been filled, Site 2; d, solid cylindrical chimneys, Site 2; e, irregular nodules, Site 3; f, tubular chimneys, the central fluid conduit is visible, Site 3.

to those found in the Gulf of Cadiz [7]. The sample morphologies are mainly tubular, Doughnut-shaped and solid cylindrical (Figure 2b-f). Most of the samples have visible fluid conduits, some have precipitates inside the conduit and show layering on the cross section (Figure 2c). Some samples do not have conduits (e.g. spiral or solid cylindrical chimneys), they are probably the imprints of the fluid channels or of trace fossils from bioturbation (Figure 2d, e). The chimneys from Site 1 and Site 2 are coated with a thin layer of brownish Fe-Mn oxides, whereas the chimneys from Site 3 are grayish or greenish and appear weakly solidified (Figure 2e, f). This indicates that the chimneys from Site 1 and Site 2 have been exposed to the seafloor for some time, and those from Site 3 are probably younger or exhumed more recently (Figure 2f). At Site 1, tubular chimneys are mostly $11-30 \mathrm{~cm}$ in length, $3.5-10 \mathrm{~cm}$ in diameter, with orifices 2 to $3 \mathrm{~cm}$ in diameter. The solid cylindrical chimneys are smaller than the tubular chimneys. They are $1-3 \mathrm{~cm}$ in diameter and 6-16 cm long (Figure $2 \mathrm{~d}$ ). The Doughnut-shaped chimneys are 3-4 cm high and about 4-13 cm in diameter. Compare to the tubular chimneys, they are shorter, but the size of the central conduit remains $2-3 \mathrm{~cm}$ in diameter, similar to those of the tubular chimneys (Table 1). At Site 2, the chimneys are usually bigger and longer than those from Site 1 . The tubular chimneys are as long as $40 \mathrm{~cm}$, and as big as $7 \mathrm{~cm}$ in diameter. The biggest Doughnut-shaped chimney collected is $18 \mathrm{~cm}$ in diameter (Figure 2c). The sizes of their central fluid conduit are close to those of Site 1, but some of them have been filled and show two layers on their cross sections. The solid cylindrical chimneys similar to those from Site 1 were also observed at Site 2 (Table 1). At Site 3, the chimneys are $7-16 \mathrm{~cm}$ long and up to $12 \mathrm{~cm}$ in diameter, shorter than those from Sites 1 and 2, while the orifice are $3-4 \mathrm{~cm}$ in diameter, bigger than those from Sites 1 and Site 2 (Figure $2 \mathrm{f}$, Table 1 ). Besides, there are many irregular or nodular samples present (Figure 2e). The differences in the size of the chimneys suggest that fluid flow at Site 3 was probably more vigorous than at Sites 1 and 2 such that the sulfate methane transition zone (SMTZ) was displaced to shallower depth and produced shorter and bigger chimneys. 
Table 1 Characteristics and distribution of the chimney-like carbonates from the northeastern Dongsha, South China Sea

\begin{tabular}{|c|c|c|c|c|}
\hline Seep sites & Morphology & Length $(\mathrm{cm})$ & Diameter $(\mathrm{cm})$ & Diameter of orifice $(\mathrm{cm})$ \\
\hline \multirow{3}{*}{ Site 1} & Tubular $(n=7)$ & $11-30$ & $3.5-10$ & $2-3$ \\
\hline & Solid cylindrical $(n=14)$ & $6-16$ & $1-3$ & - \\
\hline & Doughnut-shaped $(n=10)$ & $3-4$ & $3.5-13$ & $2-3$ \\
\hline \multirow{3}{*}{ Site 2} & Tubular $(n=9)$ & $11-40$ & $3-7$ & $2-3$ \\
\hline & Solid cylindrical $(n=8)$ & $5-16$ & $1-3$ & - \\
\hline & Doughnut-shaped ( $n=47)$ & $3-10$ & $3-18$ & $2-4$ \\
\hline \multirow[t]{2}{*}{ Site 3} & Solid cylindrical $(n=19)$ & $7-10$ & $2-3$ & - \\
\hline & Irregular nodules $(n=54)$ & $4-10$ & $3-7$ & - \\
\hline
\end{tabular}

\subsection{Petrology and mineralogy}

The chimney samples are micritic limestones. They are mainly composed of microcrystalline $\mathrm{Mg}$-calcite with abundant silt-sized quartz, minor feldspar detritus and framboidal pyrite. No recrystallization was observed (Figure 3). Pores in the size of $0.01-0.1 \mathrm{~mm}$ are present. Most of the samples show no precipitation inside the pores (Figure 3). But some samples have acicular aragonites precipitated in the pore spaces and the fluid channels.

XRD analysis showed that the chimneys are dominated by high $\mathrm{Mg}$-calcite with $\mathrm{Mg}$ content vary from 7 to 18 $\mathrm{mol} \%$ and quartz, albite, clay mineral and rare pyrite. Besides, some samples also contain low Mg-calcite, extreme high Mg-calcite $(\mathrm{Mg}=30-37 \mathrm{~mol} \%)$, rare proto-dolomite and occasionally aragonite. The fillings of the chimneys are mostly Mg-calcite with less non-carbonate mineral phases.
Seawater is unfavorable to the precipitation of $\mathrm{Mg}$-calcite due to its high sulfate and $\mathrm{Mg} / \mathrm{Ca}$ ratios [21,23]. The chimney samples are dominated by high Mg-calcite with abundant quartz and feldspar detritus indicating that they were formed from pore water in the sediments. REE analysis showed that the chimneys have positive $\mathrm{Ce}$-anomalies, this indicates that they were formed in a reducing environment [15]. When the chimneys became exposed to the seafloor, the environment changed from the more reducing pore water to the more oxidative seawater. The presence of aragonite in the pores and fluid conduits in some samples suggests that the fluid venting was active once again after the chimneys were exposed to the seafloor.

\subsection{Carbon and oxygen isotopic compositions}

The $\delta^{13} \mathrm{C}$ values of the samples vary from $-56.33 \%$ o to

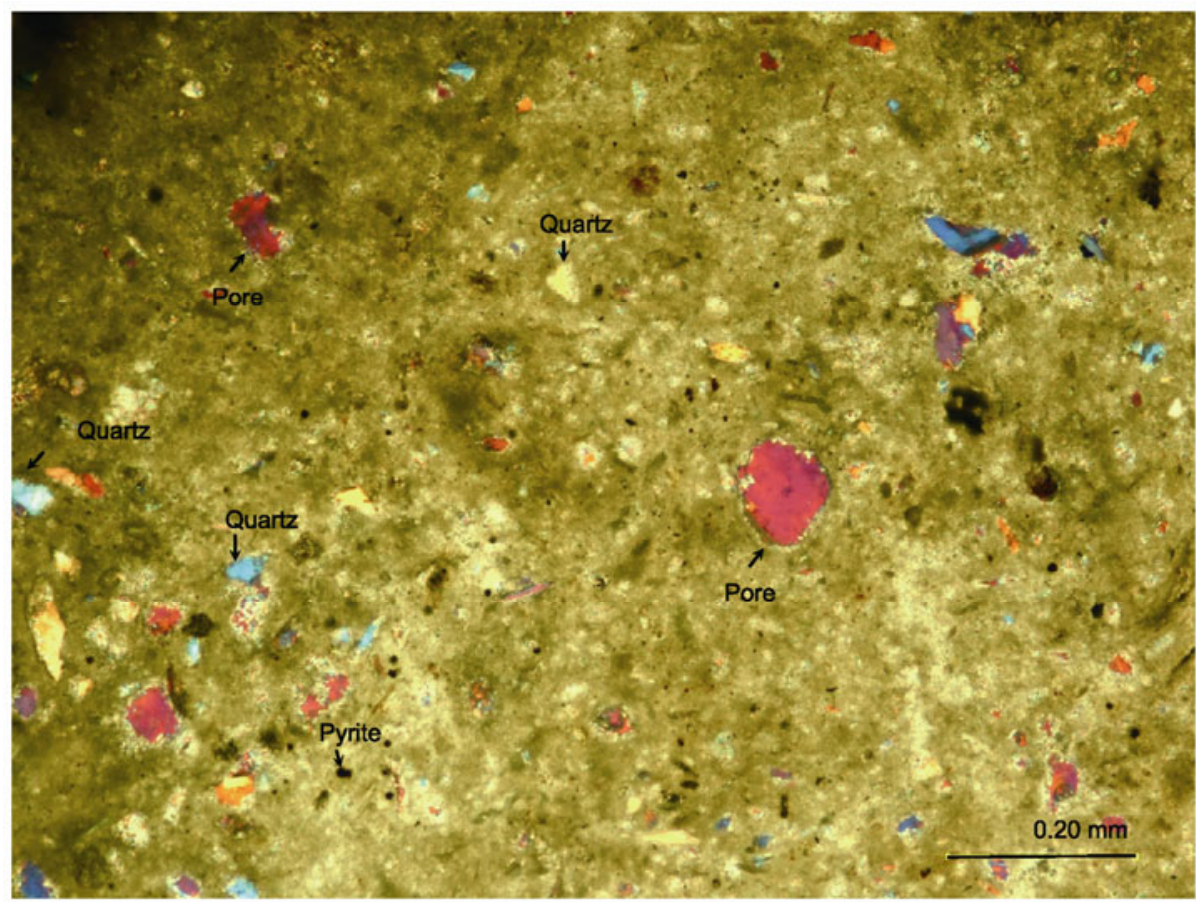

Figure 3 Microphotograph of a thin-section of a typical chimney-like carbonate sample. It is composed microcrystalline Mg-calcite containing terrestrial quartz and authigenic framboidal pyrite. Pores are present with no precipitation inside. + N, + gypsum test plate, TVG 13-C1-1, Site 2. 
$-42.70 \%$ V-PDB, and $\delta^{18} \mathrm{O}$ values from $2.76 \%$ to $5.28 \%$ o $\mathrm{V}$-PDB [5]. Those samples composed of a single $\mathrm{Mg}$-calcite phase fall into a narrower range of isotopic compositions $\left(\delta^{13} \mathrm{C}=-56.33 \%\right.$ o to $-43.79 \%$ V-PDB, $\delta^{18} \mathrm{O}=3.20 \%$ $4.80 \%$ V-PDB) (Table 2). Obviously, the samples are strongly depleted in ${ }^{13} \mathrm{C}$ which indicates that the carbonate carbon was derived from biogenic methane. Their oxygen isotopic composition is controlled by both the oxygen isotopic composition of the precipitating fluid and the temperature [24]. If calcite precipitated in isotopic equilibrium with current bottom water ( $\delta^{18} \mathrm{O}$ close to 0$)$, according to the calcite-water oxygen isotope fractionation equation and the measured bottom water temperature, theoretically, the $\delta^{18} \mathrm{O}$ value of the calcite should be $\sim 1.2 \%$ V V-PDB, $\sim 2.1 \%$ o V-PDB and $\sim 2.7 \%$ V-PDB at Sites 1, 2 and 3, respectively. However, the studied samples from these sites have $\delta^{18} \mathrm{O}$ values ranging from $3.42 \%$ to $4.80 \%$ V-PDB, which are much heavier than those of the normal seawater precipitated calcites, indicating that they probably precipitated from ${ }^{18} \mathrm{O}$ enriched fluids.

\section{Discussion}

\subsection{Oxygen isotopic compositions of the past precipitating fluids}

One prerequisite for using oxygen isotopic compositions of authigenic carbonates to reveal the nature of the precipitating fluid is that there is no further isotopic exchange occurred between the carbonates and the environment after they formed. The studied carbonates are micritic, no replacement and alteration was observed (Figure 3). Therefore we can assume that the $\delta^{18} \mathrm{O}$ of carbonates records the signal of original precipitating fluids. Using the $\delta^{18} \mathrm{O}$ of the samples and the bottom water temperatures at the sampling sites, the equilibrium $\delta^{18} \mathrm{O}$ of the precipitating fluid can be calculated. Some samples contain multi-carbonate mineral phases such as aragonite, proto-dolomite and $\mathrm{Mg}$-calcite (Table 2), in order to trace the original fluid exclusively and precisely, these samples are not discussed here.

There have been several experimental studies to determine the oxygen isotopic fractionation between inorganically precipitated calcite and water [24-27]. We adopted the expression established by Kim and O'Neil [27] to reconstruct the oxygen isotopic composition of the past precipitating fluids:

$$
10^{3} \ln \alpha_{\text {calcite-water }}=18.03\left(10^{3} / T\right)-32.42 .
$$

It is worth pointing out that Kim and O'Neil [27] used a newly determined calcite-acid fractionation factor of 1.01050 at $25^{\circ} \mathrm{C}$, whereas traditionally, the value used was 1.01025 [28]. In order to be comparable to other oxygen isotope fractionation equations, we corrected eq. (1) using the traditional calcite-acid fractionation factor of 1.01025 and obtained eq. (2):

$$
10^{3} \ln \alpha_{\text {calcite-water }}=18.03\left(10^{3} / T\right)-32.17 .
$$

In the above equations, $T$ is degree in Kelvins, and $\alpha$ is the fractionation factor which can be expressed using the following equation:

$$
\alpha_{\text {calcite-water }}=\left(1000+\delta^{18} \mathrm{O}_{\text {calcite }}\right) /\left(1000+\delta^{18} \mathrm{O}_{\text {water }}\right) \text {. }
$$

The following equation is used to convert the $\delta^{18} \mathrm{O}$ of calcite from V-PDB to V-SMOW [29]:

$$
\delta^{18} \mathrm{O}_{\mathrm{V}-\mathrm{SMOW}}=1.03091 \times \delta^{18} \mathrm{O}_{\mathrm{V}-\mathrm{PDB}}+30.91 .
$$

Since all of the studied samples were collected at or near the seafloor, it is assumed that their precipitation temperatures were equal or close to the past bottom water temperatures. Using the measured bottom water temperatures of the sampling sites as references to constrain the past bottom water temperatures, with known $\delta^{18} \mathrm{O}$ values of the samples, $\delta^{18} \mathrm{O}$ of the past precipitating fluids can be estimated according to eq. (2). Notably, the content of Mg incorporated in the crystal lattice of calcite probably affects the oxygen isotope fractionation factor. Tarutani et al. [30] reported that for each $\mathrm{mol} \%$ of $\mathrm{MgCO}_{3}$ incorporated in the crystal lattice at $25^{\circ} \mathrm{C}, 1000 \ln \alpha_{\text {calcite-water }}$ increases $0.06 \%$ o. Jimenez-Lopez et al. [31] reported that $1000 \ln \alpha_{\text {calcite-water }}$ could increase $0.17 \%$, Mavromatis et al. [32] determined the value of $0.14 \%$. The different values may be caused by different methods they applied to determine the Mg-content. We used XRD data to determine $\mathrm{Mg}$ content incorporated in the calcite, the same method as Tarutani et al. [30] used, thus the factor proposed by Tarutani et al. [30] was adopted to correct the calculation. The results show that the $\delta^{18} \mathrm{O}$ values of the precipitating fluids vary from $0.7 \%$ o to $1.9 \%$ V-SMOW, with an average of $1.4 \%$ V-SMOW (Table 2). The fillings of the chimneys recorded more ${ }^{18} \mathrm{O}$-enriched fluids than the chimney walls. This is in good agreement with REE analysis reported by Ge et al. [15], who showed that the chimney samples have a more positive $\mathrm{Ce}$ anomaly in the inner layer than the outer layer.

Several potential errors may exist when we reconstructed the $\delta^{18} \mathrm{O}$ of the past precipitating fluids: (1) the calcite precipitating temperature was assumed the same as present bottom water temperature. However, due to global climate and sea-level changes, the bottom water temperatures fluctuated in the past. Oba and Murayama [33] reported that the bottom water temperature of Kuroshio Current region (water depth 1083-2630 m) in the northwest Pacific Ocean decreased by $\sim 2.5^{\circ} \mathrm{C}$ during the last glacial maximum (LGM). The studied area is located on the upper continental slope with the water depth between 484-771 m. If and how the bottom water temperatures fluctuated in the past has never been reported. According to the temperature profiles of the water column of the study area, if the water depth decreases by $100 \mathrm{~m}$, the temperature would increase by about $1-1.5^{\circ} \mathrm{C}$ $[9,10]$. During the low sea-level stands, the bottom water temperature of the upper continental slope was influenced by the effect of global cooling but at the same time, the 


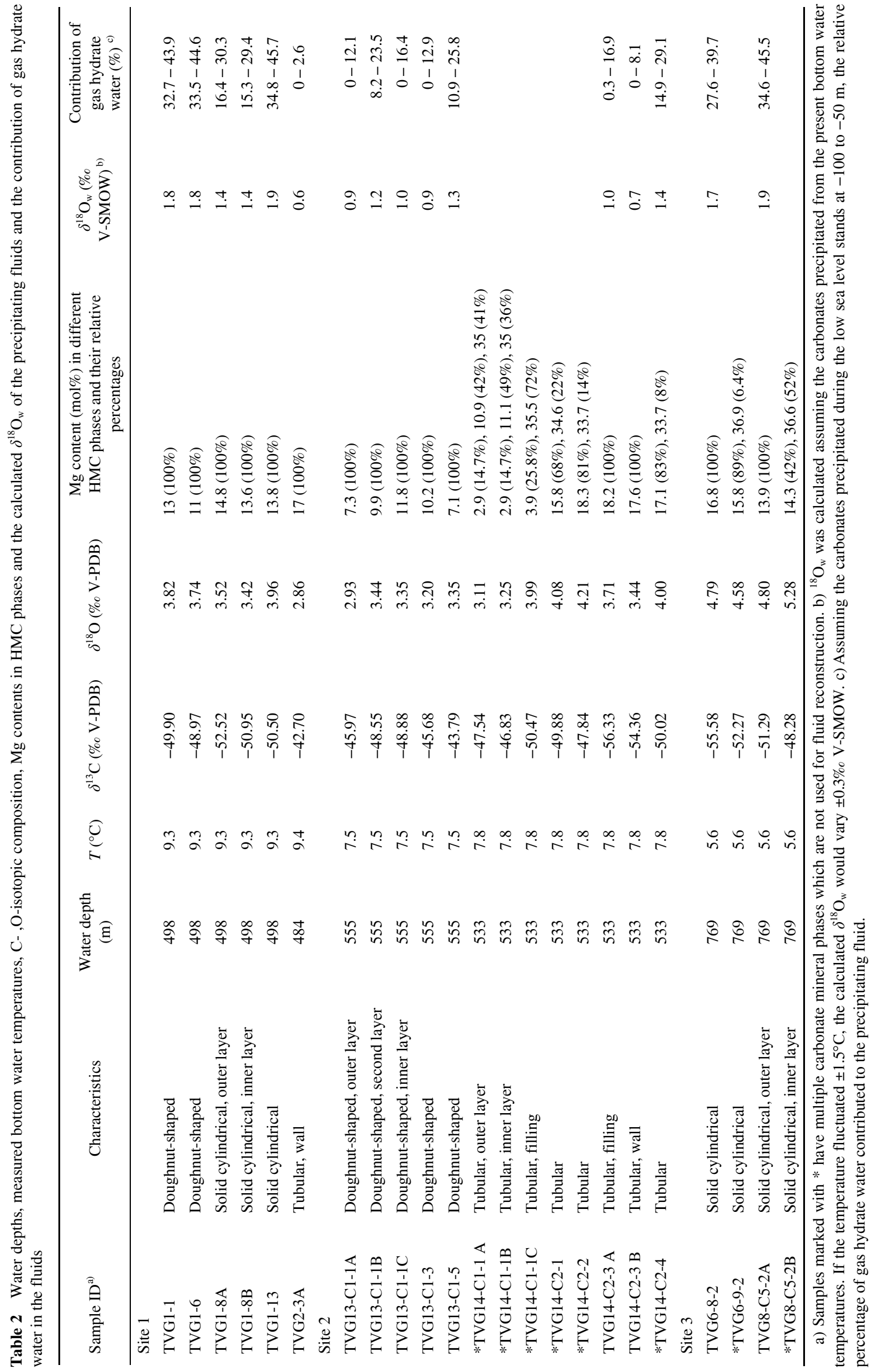


bottom water temperature would increase caused by shallower water depth. Both effects might compensate each other partly. Considering the extent of temperature change for deep water during LGM, we can assume that the past bottom water temperature at the sampling sites would be lower by $1-1.5^{\circ} \mathrm{C}$ at the maximum. Even if the past bottom water temperature was $1.5^{\circ} \mathrm{C}$ lower than at present, the calculated $\delta^{18} \mathrm{O}_{\mathrm{w}}$ values of the past precipitating fluid would be over estimated about $0.3 \%$ V-SMOW. (2) The impact of potential change of $\mathrm{pH}$ values on the $\delta^{18} \mathrm{O}$ of calcite was not considered. Recent studies show that the change of $\mathrm{pH}$ values would affect the oxygen isotopic fractionation between calcite and water. If the $\mathrm{pH}$ value decreases by one unit, the $\delta^{18} \mathrm{O}$ of calcite would be $1.42 \%$ o heavier [34]. In an active cold seep site, the processes of AOM would increase the alkalinity and $\mathrm{pH}$ of porewater due to the removal of hydrogen sulfide through precipitation of authigenic pyrite. The $\mathrm{pH}$ values may increase by 0.5 unit [35]. This could cause the $\delta^{18} \mathrm{O}$ of precipitating calcite to decrease by $0.7 \%$ o $\mathrm{V}$-PDB and cause the calculated $\delta^{18} \mathrm{O}$ of the past precipitating fluid to be under-estimated by $\sim 0.2 \%$ V-SMOW. (3) The analytical error of oxygen isotope is $\pm 0.04 \%$ V-PDB, which causes the calculated $\delta^{18} \mathrm{O}_{\mathrm{w}}$ of fluids to be uncertain by $\pm 0.01 \%$ V-SMOW. Considering the above potential errors, the $\delta^{18} \mathrm{O}$ of the past precipitating fluids $(0.7 \% 0-1.9 \%$ o $\mathrm{V}$-SMOW, average $1.4 \%$ V-SMOW) is still significantly higher than that of modern seawater (close to 0) and even heavier than the $\delta^{18} \mathrm{O}$ of seawater at LGM (1.05\% V-SMOW) [20] (Table 2). Therefore, ${ }^{18} \mathrm{O}$-enriched fluid must have been involved in the formation of these samples.

\subsection{Source and nature of venting fluid and its relationship to methane hydrate deposits}

There are potentially two sources of ${ }^{18} \mathrm{O}$-enriched deep fluids. One is gas hydrate water and the other is clay dehydration water. During the gas hydrate formation, the ${ }^{18} \mathrm{O}$ preferentially enters into the hydrate structure, such that gas hydrate water is ${ }^{18} \mathrm{O}$-enriched. The $\delta^{18} \mathrm{O}$ value of gas hydrate water could reach $3.5 \%$ V-SMOW [36,37]. The clay minerals will be dehydrated and release the structural water due to the sediment compaction and geothermal gradient. For example, smectite would be dehydrated and transforms into illite at the temperature between 60 and $160^{\circ} \mathrm{C}$. Consequently, the $\delta^{18} \mathrm{O}$ of dehydration water could be as high as 10\% V-SMOW, or even higher [38]. Previous studies on the seep carbonates and the venting fluids at Costa Rica margin showed that the clay mineral dehydration occurs at about $10 \mathrm{~km}$ below the seafloor, where the temperature is between 80 and $130^{\circ} \mathrm{C}$, and the dehydration water is enriched in $\mathrm{B}, \mathrm{Cl}$ and ${ }^{18} \mathrm{O}$ [36].

There are two types of methane involved in AOM and carbonate formation at the continental margins, one is thermogenic methane and the other is biogenic methane. The biogenic methane is produced as a direct consequence of bacterial activity and is generated at shallower depth, usually a few ten's to 100s of meters below the seabed. In contrast, the thermogenic methane is produced at high temperature and great pressure from kerogens and usually is generated at depths exceeding $1000 \mathrm{~m}$ below the seafloor. The carbonates derived from thermogenic methane are characterized by heavier $\delta^{13} \mathrm{C}$ between $-10 \%$ and $-30 \%$ o $\mathrm{V}$-PDB, but the carbonates derived from biogenic methane generally have lighter $\delta^{13} \mathrm{C}$ vlues from $-40 \%$ o to $-50 \%$ o V-PDB $[1,2,4,8]$. The $\delta^{13} \mathrm{C}$ values of the studied chimney-like carbonates vary from $-42.70 \%$ to $-56.33 \%$ o V-PDB indicating that they were overwhelmingly derived from biogenic methane. This suggests that the methane arose from shallower depths, where the temperature and pressure conditions were neither sufficient to produce methane from the thermal decomposition of organic matter nor to convert smectite to illite. Therefore, their $\delta^{18} \mathrm{O}$ values of $2.76 \% 0-5.28 \%$ V-PDB could largely be contributed to ${ }^{18} \mathrm{O}$-enriched gas hydrate water, while the contribution of clay dehydration water would be minimal or non-existent.

As the clay dehydration water is excluded from consideration, the differences in $\delta^{18} \mathrm{O}$ values between the carbonate samples are due to the different proportions of gas hydrate water and seawater, and the variation of bottom water temperatures at different sampling sites. Assuming that the chimney-like samples precipitated when the sea level was -100 to $-50 \mathrm{~m}$ lower than the present, the $\delta^{18} \mathrm{O}$ of the past seawater would be $1 \% \circ-0.5 \%$ V-SMOW [20]. According to the two-end member admixture model, it is calculated that the contribution of gas hydrate water could be as high as $45.7 \%$ (Table 2) .

\subsection{Possible mechanisms for the destruction of gas hydrate deposits}

The occurrence of chimney-like carbonates in the study area is very likely related to the destruction of gas hydrate deposits at shallow depth and release of hydrate water. According to U-Th chronology of the carbonates, the timing of methane release events mainly occurred at low sea level stands $[18,19]$. The geological and geochemical conditions of the study area are favorable for gas hydrate formation, and the natural gas hydrate have been drilled at the Shenhu area $\left(19.9^{\circ} \mathrm{N}, 115.2^{\circ} \mathrm{E}\right)$ at $153-225 \mathrm{~m}$ below seafloor [39] confirming that there exists gas hydrates in the South China Sea.

Gas hydrates are stable only under the condition of low temperature and high pressure. There are two possible mechanisms responsible for the destruction and dissociation of gas hydrates in the study area: (1) decrease of the hydrostatic pressure due to the sea level drop would cause gas hydrates at shallow depth out of stabilization zone and dissociation; and (2) erosion as evidenced by deep and V-shaped valleys, canyons, gullies, and channels cutting in the study area would also cause some gas hydrates out of 
stability zone. Associated slumping and block movement would accelerate gas hydrate destruction.

As a greenhouse gas, the methane released from gas hydrate dissociation would cause a potential serious threat to the global warming. The enhanced microbial activity carried out by the syntrophic consortia of sulfate-reducing bacteria and methane-oxidizing archaea at the SMTZ however, would consume a large amount of methane $[3,13,40]$. The widely distributed chimney-like seep carbonates in the study area indicate that massive methane released from the gas hydrate dissociation has been transformed into carbonates and thus sequestered the greenhouse gas through microbial anaerobic oxidation before it leaked to the sea water and possibly into the atmosphere.

\section{Conclusions}

Based on the studies on the occurrence, morphology, petrology, mineralogy and $\mathrm{C}$ - and O-isotopes of the chimney-like seep carbonates in the northeastern slope of the South China Sea, the source and nature of the methaneenriched fluids and the relationship to the sub-bottom gas hydrate deposits are discussed. The following conclusions are drawn:

The chimney-like carbonates from the northeastern slope of the South China Sea originally formed around the fluid channels in the sediments and later exposed to the seafloor due to submarine erosion and excavation by currents or sediment slumping. The carbonates are dominated by high$\mathrm{Mg}$ calcite and characterized by extremely light $\delta^{13} \mathrm{C}$ composition $\left(-56.3 \%\right.$ o to $-43.8 \%$ V-PDB) and heavy $\delta^{18} \mathrm{O}$ (3.2\%o-4.8\%o V-PDB). They were derived from biogenic methane and their formation was associated with the expulsion of ${ }^{18} \mathrm{O}$-enriched fluids. Calculation shows that the $\delta^{18} \mathrm{O}$ of the precipitating fluids were in the range of $1.9 \pm 0.3 \%$ $0.7 \pm 0.3 \%$ o -SMOW (average of $1.4 \pm 0.3 \%$ o V-SMOW).

The precipitating fluids are mixtures of gas hydrate water and seawater. Gas hydrate water contributes as much as $45.7 \%$.

It is further inferred that shallow sub-bottom gas hydrate deposits in the study area were subjected to destruction and released large amounts of methane-rich fluids in the past. Hydrostatic decrease and submarine canyon carving due to lowered sea-level and environmental changes related to glacial-interglacial cycles are the mechanisms likely responsible for the gas hydrate destabilization here. However, a considerable amount of methane released from gas hydrate destabilization were oxidized and is sequestered by formation of seep carbonates via microbial anaerobic oxidation before it leakes into the water column and atmosphere.

We thank the crew and scientific party of SO177 cruise for their support and help. Prof. Suess Erwin and Dr. Chen Yifeng are warmly thanked for constructive discussions during the paper preparation. Wu Nengyou, Feng
Dong and Chen Duofu are thanked for their review and comments. This work was supported by the National Basic Research Program of China (2009CB21950607), Zhejiang Provincial Natural Science Foundation of China (R5110215) and the National Natural Science Foundation of China (40976040).

1 Suess E. Marine cold seeps. In: Timmis K N, ed. Handbook of Hydrocarbon and Lipid Microbiology. Heidelberg: Springer, 2010. 187203

2 Campbell K A. Hydrocarbon seep and hydrothermal vent paleoenvironments and paleontology: Past developments and future research directions. Palaeogeogr Palaeoclimat Palaeoecol, 2006, 232: 362-407

3 Boetius A, Ravenschlag K, Schubert C J, et al. A marine consortium apparently mediating anaerobic oxidation of methane. Nature, 2000, 407: 623-626

4 Han X, Suess E, Sahling H, et al. Fluid venting activity on the Costa Rica margin: New results from authigenic carbonates. Int J Earth Sci, 2004, 93: 596-611

5 Han X, Suess E, Huang Y, et al. Jiulong methane reef: Microbial mediation of seep carbonates in the South China Sea. Mar Geol, 2008, 249: 243-256

6 Diaz-del-Rio V, Somoza L, Martinez-Frias J, et al. Vast fields of hydrocarbon-derived carbonate chimneys related to the accretionary wedge/olistostrome of the Gulf of Cadiz. Mar Geol, 2003, 195: 177200

7 Magalhães V H, Pinheiro L M, Ivanov M K, et al. Formation processes of methane-derived authigenic carbonates from the Gulf of Cadiz. Sediment Geol, 2011, 243-244: 255-268

8 Bohrmann G, Greinert J, Suess E, et al. Authigenic carbonates from the Cascadia subduction zone and their relation to gas hydrate stability. Geology, 1998, 26: 647-650

9 Suess E, Huang Y, Wu N, et al. South China Sea: Distribution, formation and effect of methane and gas hydrate on the environment, IFM-GEOMAR Report No. 4: RV Sonne Fahrtbericht/Cruise Report SO 177,2005

10 Huang Y, Suess E, Wu N, et al. Methane and gas hydrate geology of the Northern South China Sea: Sino-German Cooperative SO-177 Cruise Report (in Chinese). Beijing: Geological Publishing House, 2008

11 Chen D F, Huang Y Y, Yuan X L, et al. Seep carbonates and preserved methane oxidizing archaea and sulfate reducing bacteria fossils suggest recent gas venting on the seafloor in the northeastern South China Sea. Mar Petrol Geol, 2005, 22: 613-621

12 Lu H, Liu J, Chen F, et al. Mineralogy and stable isotopic composition of authigenic carbonates in bottom sediments in the offshore area of southwest Taiwan, South China Sea: Evidence for gas hydrates occurrence (in Chinese). Earth Sci Front, 2005, 3: 268-276

13 Yu X, Han X, Li H, et al. Biomarkers and carbon isotope composition of anaerobic oxidation of methane in sediments and carbonates of northeastern part of Dongsha, South China Sea (in Chinese). Acta Oceanol Sin, 2008, 30: 77-84

14 Birgel D, Elvert M, Han X, et al. ${ }^{13} \mathrm{C}$-depleted biphytanic diacids as tracers of past anaerobic oxidation of methane. Org Geochem, 2008, 39: $152-156$

15 Ge L, Jiang S, Swennen R, et al. Chemical environment of cold seep carbonate formation on the northern continental slope of South China Sea: Evidence from trace and rare earth element geochemistry. Mar Geol, 2010, 277: 21-30

16 Ge L, Jiang S, Yang T, et al. Glycerol ether biomarkers and their carbon isotopic compositions in a cold seep carbonate chimney from the Shenhu area, northern South China Sea. Chin Sci Bull, 2011, 56: 1700-1707

17 Chen X, Han X. Carbon and oxygen isotope characteristics of the growth profile of a seep carbonate chimney from the northeastern slope of the South China Sea and its formation model (in Chinese). Acta Sedimentol Sin, 2013, 31: 50-55

18 Han X, Suess E, Liebtrau V, et al. The sources and pathways of palaeo-fluid recorded by cold seep carbonates: Implication on the fate of gas hydrate of the South China Sea. Eos Trans 87(36), AGU, West 
Pac Geophys Meet Suppl, Abstract V35B-06, 2006

19 Han X, Suess E, Liebtrau V, et al. Ages of seep carbonates from the northern slope of the South China Sea and the destruction of shallow gas hydrate deposits in the past (in Chinese). Cross Straits Workshop on Marginal Sea Geology, Resources and Environmental Effects, 2007, 11.26-11.27, Guangzhou

20 Duplessy J C, Labeyrie L, Waelbroeck C. Constraints on the ocean oxygen isotopic enrichment between the last glacial maximum and the Holocene: Paleoceanographic implications. Quat Sci Rev, 2002, 21: $315-330$

21 Peckmann J, Reimer A, Luth U, et al. Methane-derived carbonates and authigenic pyrite from the northwestern Black Sea. Mar Geol, 2001, 177: 129-150

22 Goldsmith J, Graf D, Heard H. Lattice constants of the calciummagnesium carbonates. Am Mineral, 1961, 46: 453-457

23 De Choudens-Sanchez V, Gonzalez L. Calcite and aragonite precipitation under controlled instantaneous supersaturation: Elucidating the role of $\mathrm{CaCO}_{3}$ saturation state and $\mathrm{Mg} / \mathrm{Ca}$ ratio on calcium carbonate polymorphism. J Sed Res, 2009, 79: 363-376

24 Urey H C. The thermodynamic properties of isotopic substances. J Chem Soc, 1947, 562-581

25 Epstein S, Buchsbaum R, Lowenstam H A, et al. Revised carbonatewater isotopic temperature scale. Geol Soc Am Bull, 1953, 64: 13151326

26 Friedman I, O' Neil J R. Compilation of fractionation factors of geochemical interest. Data of Geochemistry, 6th ed. USGS Professional Paper, 1977

27 Kim S T, O'Neil J R. Equilibrium and nonequilibrium oxygen isotope effects in synthetic carbonates. Geochim Cosmochim Acta, 1997, 61: 3461-3475

28 Mccrea J M. On the isotopic composition of carbonates and a paleotemperature scale. J Chem Phys, 1950, 18: 849-857

29 Coplen T B, Kendall C, Hopple J. Comparison of stable isotope reference material. Nature, 1983, 302: 236-238

30 Tarutani T, Clayton R N, Mayeda T K. The effect of polymorphism and magnesium substitution on oxygen isotope fractionation between calcium carbonate and water. Geochim Cosmochim Acta, 1969, 33: 987-996

31 Jimenez-Lopez C, Romanek C S, Huertas F J, et al. Oxygen isotope fractionation in synthetic magnesian calcite. Geochim Cosmochim Acta, 2004, 68: 3367-3377

32 Mavromatis V, Schmidt M, Botz R, et al. Experimental quantification of the effect of $\mathrm{Mg}$ on calcite-aqueous fluid oxygen isotope fractionation. Chem Geol, 2012, 310-311: 97-105

33 Oba T, Murayama M. Sea-surface temperature and salinity changes in the northwest pacific since the last glacial maximum. J Quat Sci, 2004, 19: 335-346

34 Zeebe R E. An explanation of the effect of seawater carbonate concentration on foraminiferal oxygen isotopes. Geochim Cosmochim Acta, 1999, 63: 2001-2007

35 Treude T, Niggemann J, Kallmeyer J, et al. Anaerobic oxidation of methane and sulfate reduction along the Chilean continental margin. Geochim Cosmochim Acta, 2005, 69: 2767-2779

36 Hensen C, Wallmann K, Schmidt M, et al. Fluid expulsion related to mud volcanism at Costa Rica continental margin-A window to the subducting slab. Geology, 2004, 32: 201-204

37 Matsumoto R, Borowski W. Gas hydrate estimates from newly determined oxygen isotopic fractionation $\left(\alpha_{\mathrm{GH}-\mathrm{IW}}\right)$ and $\delta^{18} \mathrm{O}$ anomalies of the interstitial waters: Leg 164, Blake Ridge. Proc ODP Sci Res, 2000, 164: 59-66

38 Dahlmann A, De Lange G J. Fluid-sediment interactions at eastern mediterranean mud volcanoes: A stable isotope study from ODP leg 160. Earth Planet Sci Lett, 2003, 212: 377-391

39 Wu N, Zhang H, Yang S, et al. Preliminary discussion on natural gas hydrate reservoir system of Shenhu area, north slope of the South China Sea (in Chinese). Nat Gas Ind, 2007, 27: 1-6

40 Su X, Chen F, Wei S, et al. Preliminary study on the correlation between microbial abundance and methane concentration in sediments from cold seeps in the northern South China Sea (in Chinese). Geosci-J Grad School Chin Univ Geosci, 2007, 21: 101-104

Open Access This article is distributed under the terms of the Creative Commons Attribution License which permits any use, distribution, and reproduction in any medium, provided the original author(s) and source are credited. 